\title{
HUBUNGAN TINGGI BADAN IBU, SOSIAL EKONOMI DAN ASUPAN SUMBER ZINC DENGAN KEJADIAN STUNTING PADA ANAK USIA 3-5 TAHUN DI PUSKESMAS KOPELMA DARUSSALAM
}

\author{
Muhammad Haris Ramadhan ${ }^{1}$, Liza Salawati ${ }^{2}$, Sulaiman Yusuf $^{3}$ \\ 1) Mahasiswa Fakultas Kedokteran Unsyiah \\ 2) Bagian Kesehatan Masyarakat Fakultas Kedokteran Unsyiah \\ 3) Bagian Ilmu Kesehatan Anak Rumah Sakit Umum Daerah dr.Zainoel Abidin \\ Corresponding author : lizasalawati.dr@gmail.com
}

\begin{abstract}
Abstrak
Stunting merupakan status gizi masa lalu yang kurang baik akibat asupan gizi kurang, baik kualitas maupun kuantitas sehingga tinggi badan tidak sesuai dengan umur. Banyak faktor yang dapat menyebabkan stunting antara lain: defisiensi gizi makro dan mikro, genetik, sosial ekonomi, penyakit infeksi, pemberian air susu ibu ekslusif dan berat badan lahir rendah. Tujuan dari penelitian ini adalah mengetahui hubungan tinggi badan ibu, sosial ekonomi dan asupan sumber zinc dengan stunting pada anak usia 3-5 tahun di Puskesmas Kopelma Darussalam Banda Aceh. Jenis penelitian analitik observasional dengan design cross sectional. Pengambilan sampel tanggal 14 September sampai 14 November 2017 di 5 posyandu Puskesmas Kopelma Darussalam secara non probability sampling dengan metode accidental sampling. Penilaian tinggi badan ibu dan stunting dengan mengukur tinggi badan menggunakan mikrotoa, sosial ekonomi dan asupan sumber zinc diukur menggunakan kuesioner. Jumlah sampel sebanyak 46 ibu dan anak yang memenuhi kriteria inklusi. Anak usia 3-5 tahun stunting (pendek atau sangat pendek) sebesar 41,3\%, tinggi badan ibu pendek $50 \%$, sosial ekonomi rendah $52,2 \%$ dan asupan sumber zinc kurang $50 \%$. Uji analisis Spearman terdapat hubungan antara tinggi badan ibu dengan stunting nilai $\mathrm{p}=0,000$ $(\mathrm{p}<0,05)$ dan $\mathrm{r}=0,529$ kekuatan hubungan kuat. Tidak terdapat hubungan sosial ekonomi dengan stunting nilai $\mathrm{p}=0,930(\mathrm{p}>0,05)$ dan terdapat hubungan asupan sumber zinc dengan stunting nilai $\mathrm{p}=0,016(\mathrm{p}<0,05)$ dan $\mathrm{r}=0,352$ kekuatan hubungan sedang. Kesimpulannya, tinggi badan ibu dan asupan sumber zinc berhubungan dengan stunting dan tidak terdapat hubungan antara sosial ekonomi dengan stunting.
\end{abstract}

Kata kunci: Stunting, tinggi badan ibu, sosial ekonomi, asupan sumber zinc

\section{Relationship between Mother's High, Social Economy and Zinc Source Intake with Stunting who Aged 3-5 Years at Puskesmas Darussalam Kopelma}

\begin{abstract}
Stunting is a past nutritional status which is less good due to lack of nutritional intake, both quality and quantity so the height is not appropriate with age. Many factors that can lead to stunting include: macro and micro nutritional deficiencies, genetic, socioeconomic, infectious diseases, exclusive breast feeding and low birth weight. The purpose is knowing the correlation between mother's height, socioeconomic and intake of zinc source with
\end{abstract}


stunting at 3-5 years old at Kopelma Darussalam Public Health Center Banda Aceh. The Method is observational analytic research with cross sectional design. Sampling from 14 September to 14 November 2017 at 5 Maternal and Child Health Services Kopelma Darussalam Public Health Center with non probability sampling on accidental sampling method. Result of the research shows there are 46 mothers and children who meet the inclusion criteria. Children aged 3-5 years stunting (short or very shor) $41.3 \%$, short mother $50 \%$, low social economics $52.2 \%$ and intake of zinc source less $50 \%$. Spearman analysis test there is relationship between mother's height with stunting value $p=0,000(p<0,05)$ and $r=$ 0,529 strong relation strength. There is no relationship between socioeconomic with stunting, value of $p=0,930(p>0,05)$ and there is correlation of intake of zinc source with stunting, value $\mathrm{p}=0,016(\mathrm{p}<0,05)$ and $\mathrm{r}=0,352$ medium relation strength. Conclusion is maternal height and zinc source intake are associated with stunting and there is no relationship between socioeconomic and stunting.

Keywords: Stunting, maternal height, socioeconomic, zinc source intake

\section{PENDAHULUAN}

Gizi merupakan salah satu faktor penting yang menentukan tingkat kesehatan dan kesejahteraan manusia. Gizi yang baik apabila terdapat keseimbangan antara perkembangan fisik dengan mental seseorang. Status gizi erat kaitannya dengan konsumsi makanan yang akan tercapai apabila kebutuhan zat gizi optimal terpenuhi. ${ }^{(1)}$ Menurut United Nations International Children's Emergency Fund (UNICEF) sepertiga anak-anak dibawah usia lima tahun di negara-negara berkembang memiliki tubuh pendek (stunting). Menurut Laporan The Lancet's prevalensi balita stunting di seluruh dunia mencapai $28,5 \%$ dan negara berkembang $31,2 \%{ }^{(2)}$ Data World Health Organization (WHO) tahun 2015 prevalensi stunting di Asia Tenggara $32,9 \%$ dengan angka kejadiannya 58,9 juta orang. ${ }^{(3)}$ Menurut WHO prevalensi stunting dikatakan tinggi apabila mencapai 30\% sampai 39\% dan sangat tinggi jika $\geq 40 \%$. ${ }^{(4)}$ Prevalensi stunting di Indonesia termasuk kategori tinggi berdasarkan Riset Kesehatan Dasar (RISKESDAS) tahun 2013, yaitu sebesar 37,2\%, terdiri dari 18\% sangat pendek dan 19,2\% pendek. Terjadi peningkatan dibandingkan tahun 2007 yaitu 36,8\% dan 2010 sebesar 35,6\%. ${ }^{(5)}$ Prevalensi stunting di Provinsi Aceh tahun 2014 sebesar 38,9\%, terdiri dari $24,2 \%$ sangat pendek dan 14,7\% pendek. Angka stunting ini masih tinggi dibanding prevalensi nasional yaitu 37,2\%. ${ }^{(5)(6)}$ Prevalensi stunting di Kota Banda Aceh tahun 2013 sebesar 30,7\%, terdiri dari 12,3\% sangat pendek dan 18,4\% pendek. ${ }^{(5)}$ Pemerintah Indonesia tahun 2017 menargetkan angka balita stunting turun 2\% atau 3\% tiap tahunnya. ${ }^{(6)}$ Pada tahun 2010 prevalensi stunting sebesar $50 \%$ dan severe stunting sebesar $24 \%$ terjadi pada anak usia $2-5$ tahun. $^{(7)}$ 
Anak yang lahir dari ibu dengan tinggi badan $\leq 150 \mathrm{~cm}$ memiliki risiko $30,8 \%$ lebih tinggi untuk terjadinya stunting. Sedangkan anak yang dilahirkan dari ibu dengan tinggi badan $>150 \mathrm{~cm}$ memiliki risiko 13,6\% lebih rendah unuk terjadinya stunting. Tinggi badan ibu berkaitan dengan stunting. Stunting juga berhubungan dengan sosio ekonomi, oleh karena pendapatan akan mempengaruhi pemenuhan zat gizi keluarga. Makanan seperti daging sapi, ayam dan ikan laut yang kaya akan zinc dan protein sulit didapat, sehingga stunting lebih tinggi pada keluarga dengan sosio ekonomi rendah. ${ }^{(8)}$ Terjadi peningkatan rasio status gizi stunting pada keluarga dengan sosio ekonomi rendah. ${ }^{(8)(9)}$ Sumber Zinc banyak berasal dari sumber protein hewani, seperti daging, hati, kerang dan telur. Sumber protein nabati seperti kacangkacangan dan serelia juga banyak mengandung zinc, namun bioavailability rendah. Kekurangan zinc menyebabkan terjadinya stunting pada anak, karena zinc mempunyai peran utama dalam sintesis protein, replikasi gen dan pembelahan sel yang penting selama periode percepatan pertumbuhan baik sebelum maupun sesudah kelahiran. ${ }^{(10)}$ Balita dari keluarga dengan status ekonomi rendah berisiko 1,29 kali mengalami stunting dibandingkan balita dari keluarga dengan status ekonomi tinggi. Hal ini berkaitan dengan jumlah anggota keluarga, keluarga butuh kemampuan lebih untuk menyediakan makanan dalam jumlah besar apabila jumlah anggota dalam keluarga banyak. Keluarga dengan jumlah anggota cukup atau sedikit akan mudah untuk memenuhi ketersediaan makanan, sehingga risiko mempunyai anak malnutrisi lebih sedikit dibandingkan keluarga dengan jumlah anggota yang banyak. ${ }^{(11)}$

\section{METODOLOGI PENELITIAN}

Jenis penelitian observasional analitic dengan desain cross sectional. Pengambilan data tanggal 14 September sampai 14 November 2017, di semua posyandu wilayah kerja Puskesmas Kopelma Darussalam Banda Aceh tahun 2017 berjumlah 5 posyandu, yaitu Posyandu Seulanga Indah, Harapan Mulia, Kayee Adang, Cut Nyak Dien dan Bina Sejahtera. Populasi adalah ibu dan anaknya yang berusia 3-5 tahun di wilayah kerja Puskesmas Kopelma Darussalam Banda Aceh tahun 2017. Sampel adalah ibu dan anaknya yang berusia 3-5 tahun yang datang ke 5 Posyandu yang memenuhi kriteria inklusi yaitu, anak berusia 3-5 tahun, ibu dan anaknya yang bersedia mengikuti penelitian dan hadir di posyandu. Teknik pengambilan sampel adalah non probability sampling dengan metode accidental sampling. Analisa data yang digunakan univariat dan bivariat dengan uji statistik Korelasi Rank Spearman. 


\section{HASIL}

Jumlah responden adalah 46 ibu dan anak yang memenuhi kriteria inklusi. Data karakteristik umum responden disajikan dalam tabel sebagai berikut:

1. Karakteristik Umum Responden

Tabel 1 Distribusi Frekuensi Karateristik Responden di Posyandu Puskesmas Kopelma Darussalam

\begin{tabular}{|c|c|c|}
\hline $\begin{array}{c}\text { Karakteristik } \\
\text { Umum }\end{array}$ & $\begin{array}{c}\text { Frekuensi } \\
(n=46)\end{array}$ & $\begin{array}{c}\text { Persentase } \\
(\%)\end{array}$ \\
\hline \multicolumn{3}{|l|}{ Jenis Kelamin } \\
\hline Laki-laki & 22 & 47,8 \\
\hline Perempuan & 24 & 52,2 \\
\hline \multicolumn{3}{|l|}{ Umur Ibu (Tahun) } \\
\hline $24-35$ & 26 & 56,5 \\
\hline $36-45$ & 20 & 43,5 \\
\hline \multicolumn{3}{|l|}{ Pekerjaan Ibu } \\
\hline PNS & 10 & 21,7 \\
\hline Swasta & 3 & 6,5 \\
\hline IRT & 33 & 71,7 \\
\hline \multicolumn{3}{|l|}{ Pendidikan Ibu } \\
\hline SMP & 4 & 8,7 \\
\hline SMA & 25 & 54,3 \\
\hline D3 & 6 & 13,0 \\
\hline S1 & 11 & 23,9 \\
\hline \multicolumn{3}{|l|}{ Posyandu } \\
\hline Seulanga Indah & 5 & 10,9 \\
\hline Harapan Mulia & 13 & 28,3 \\
\hline Kayee Adang & 7 & 15,2 \\
\hline Cut Nyak Dien & 12 & 26,1 \\
\hline Bina Sejahtera & 9 & 19,6 \\
\hline
\end{tabular}

Berdasarkan tabel 1, dari 46 responden, jenis kelamin perempuan lebih dominan yaitu 24 anak (52,2\%). Kelompok umur ibu 24-35 tahun lebih banyak yaitu 26 ibu (56,5\%). Bekerja sebagai IRT sebanyak 33 ibu (71,7\%). Ibu berpendidikan SMA berjumlah 25 ibu (54,3\%). Kehadiran di Posyandu Harapan Mulia lebih dominan yaitu 13 responden (28,3\%).

\section{Stunting}

Pembagian stunting dalam penelitian ini apabila anak memiliki tinggi badan pendek atau sangat pendek (skor Z TB/U <-2.0 SD). Berdasarkan hasil pengukuran TB anak terhadap umur (TB/U) didapatkan klasifikasi stunting pada anak usia 3-5 tahun di Posyandu Puskesmas Kopelma Darussalam yang dapat dilihat pada tabel 2. 
Tabel 2 Distribusi Frekuensi Stunting Pada Anak Usia 3-5 Tahun di Posyandu Puskesmas Kopelma Darussalam.

\begin{tabular}{lrr}
\hline \multicolumn{1}{c}{$\begin{array}{c}\text { Stunting } \\
\text { (TB/U) }\end{array}$} & n & \% \\
\hline Normal & & 58,7 \\
Pendek & 27 & 23,9 \\
Sangat Pendek & 11 & 17,4 \\
Tinggi & 8 & 0,0 \\
\hline
\end{tabular}

Tabel 2 di atas menunjukkan bahwa anak usia 3-5 tahun yang memiliki tinggi badan normal lebih dominan yaitu 27 anak $(58,7 \%)$.

3. Tinggi Badan Ibu

Berdasarkan hasil pengukuran tinggi badan ibu didapatkan hasil yang dapat dilihat pada tabel 3 .

Tabel 3 Distribusi Frekuensi Tinggi Badan Ibu di Posyandu Puskesmas Kopelma Darussalam

\begin{tabular}{lcc}
\hline Tinggi Badan Ibu & n & \% \\
\hline Normal & 23 & 50,0 \\
Pendek & 23 & 50,0 \\
\hline
\end{tabular}

Tabel 3 menunjukkan, ibu yang memiliki tinggi badan normal dan pendek sama- sama berjumlah $23 \mathrm{ibu}(50 \%)$.

4. Sosial Ekonomi Keluarga

Berdasarkan hasil wawancara status soal ekonomi keluarga didapatkan hasil yang dapat dilihat pada tabel 4 .

Tabel 4 Distribusi Frekuensi Karakteristik Sosial Ekonomi Keluarga di Posyandu Puskesmas Kopelma Darussalam

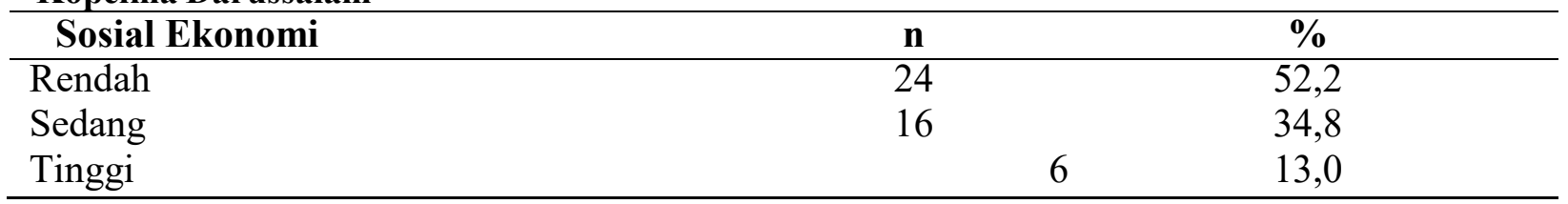

Berdasarkan tabel 4, status sosial ekonomi rendah lebih banyak yaitu 24 orang (52,2\%).

5. Asupan Sumber Zinc

Pengukuran asupan sumber zinc pada anak diklasifikasikan 2 kelompok yang hasilnya dapat dilihat pada tabel 5 .

Tabel 5 Distribusi Frekuensi Karakteristik Sosial Ekonomi Keluarga di Posyandu Puskesmas Kopelma Darussalam

\begin{tabular}{lcc}
\hline Asupan Sumber Zinc & n & \% \\
\hline Kurang & 23 & 50,0 \\
Baik & 23 & 50,0 \\
\hline
\end{tabular}


Berdasarkan tabel 5 di atas, didapatkan asupan sumber zinc baik dan kurang sama- sama berjumlah 23 orang $(50 \%)$.

\section{Hubungan Tinggi Badan Ibu dengan Stunting}

Tabel 6 Hubungan Tinggi Badan Ibu dengan Stunting Pada Anak Usia 3-5 Tahun di Posyandu Puskesmas Kopelma Darussalam

\begin{tabular}{|c|c|c|c|c|c|c|c|c|c|c|}
\hline \multirow{3}{*}{$\begin{array}{c}\text { Tinggi } \\
\text { Badan Ibu }\end{array}$} & \multicolumn{6}{|c|}{ Stunting } & \multirow{2}{*}{\multicolumn{2}{|c|}{ Total }} & \multirow[t]{2}{*}{ pvalue } & \multirow[t]{2}{*}{$\mathbf{r}$} \\
\hline & \multicolumn{2}{|c|}{ Normal } & \multicolumn{2}{|c|}{ Pendek } & \multicolumn{2}{|c|}{ Sangat Pendek } & & & & \\
\hline & $\mathrm{n}$ & $\%$ & $\mathrm{n}$ & $\%$ & $\mathrm{n}$ & $\%$ & $\mathrm{n}$ & $\%$ & & \\
\hline Pendek & 8 & 34,8 & 7 & 30,4 & 8 & 34,8 & 23 & 100 & 0,000 & 0,529 \\
\hline Normal & 19 & 82,6 & 4 & 17,4 & 0 & 0,0 & 23 & 100 & & \\
\hline
\end{tabular}

Tabel 6 menunjukkan bahwa ibu dengan badan normal cenderung memiliki anak dengan tinggi badan yang normal yaitu $82,6 \%$, sedangkan ibu dengan tinggi badan pendek $34,8 \%$ memiliki anak dengan tinggi badan normal. Hasil Uji Korelasi Rank Spearman, didapatkan P value = $0,000(\mathrm{p}<0,05)$, terdapat hubungan antara tinggi badan ibu dengan kejadian stunting pada anak usia 3-5 tahun di Puskesmas Kopelma Darussalam dengan nilai r = 0,529 yang berarti kekuatan hubungan kuat.

\section{Hubungan Sosial Ekonomi dengan Stunting}

Tabel 7 Hubungan Sosial Ekonomi dengan Stunting Pada Anak Usia 3-5 Tahun di Posyandu Puskesmas Kopelma Darussalam

\begin{tabular}{|c|c|c|c|c|c|c|c|c|c|c|}
\hline \multirow{3}{*}{$\begin{array}{c}\text { Sosial } \\
\text { Ekonomi }\end{array}$} & \multicolumn{6}{|c|}{ Stunting } & \multirow{2}{*}{\multicolumn{2}{|c|}{ Total }} & \multirow[t]{2}{*}{ pvalue } & \multirow[t]{2}{*}{$\mathbf{r}$} \\
\hline & \multicolumn{2}{|c|}{ Normal } & \multicolumn{2}{|c|}{ Pendek } & \multicolumn{2}{|c|}{ Sangat Pendek } & & & & \\
\hline & $\mathrm{n}$ & $\%$ & $\mathrm{n}$ & $\%$ & $\mathrm{r}$ & $\%$ & $\mathrm{n}$ & $\%$ & \multirow{4}{*}{0,930} & \multirow{4}{*}{0,013} \\
\hline Rendah & 14 & 58,3 & 5 & 20,8 & 5 & 20,8 & 24 & 100 & & \\
\hline Sedang & 10 & 62,5 & 4 & 25,0 & 2 & 12,5 & 16 & 100 & & \\
\hline Tinggi & 3 & 50,0 & 1 & 16,7 & 2 & 33,3 & 6 & 100 & & \\
\hline
\end{tabular}

Tabel 7 menunjukkan bahwa keluarga dengan sosial ekonomi sedang cenderung memiliki anak dengan tinggi badan normal 62,5\%, sedangkan keluarga dengan sosial ekonomi tinggi memiliki anak dengan tinggi badan normal 50\%. Hasil Uji Kolerasi Rank Spearman, didapatkan $\mathrm{P}$ value $=0,930(\mathrm{p}>0,05)$, tidak terdapat hubungan antara sosial ekonomi dengan kejadian stunting pada anak usia 3-5 tahun di Puskesmas Kopelma Darussalam. 


\section{Hubungan Asupan Sumber Zinc dengan Stunting}

Tabel 8 Hubungan Asupan Sumber Zinc dengan Stunting Pada Anak Usia 3-5 Tahun di Posyandu Puskesmas Kopelma Darussalam

\begin{tabular}{|c|c|c|c|c|c|c|c|c|c|c|}
\hline \multirow{3}{*}{$\begin{array}{c}\text { Asupan } \\
\text { Sumber } \\
\text { Zinc }\end{array}$} & \multicolumn{6}{|c|}{ Stunting } & \multirow{2}{*}{\multicolumn{2}{|c|}{ Total }} & \multirow[t]{2}{*}{ pvalue } & \multirow[t]{2}{*}{$\mathbf{r}$} \\
\hline & \multicolumn{2}{|c|}{ Normal } & \multicolumn{2}{|c|}{ Pendek } & \multicolumn{2}{|c|}{ Sangat Pendek } & & & & \\
\hline & $\mathrm{n}$ & $\%$ & $\mathrm{n}$ & $\%$ & $\mathrm{n}$ & $\%$ & $\mathrm{n}$ & $\%$ & \multirow{3}{*}{0,016} & \multirow{3}{*}{0,352} \\
\hline Kurang & 9 & 39,1 & 9 & 39,1 & 5 & 21,8 & 23 & 100 & & \\
\hline Baik & 18 & 78,3 & 2 & 8,7 & 3 & 13,0 & 23 & 100 & & \\
\hline
\end{tabular}

Tabel 8 menunjukkan bahwa asupan sumber zinc yang baik pada anak cenderung memiliki tinggi badan normal sebanyak 78,3\%, sedangkan asupan sumber zinc yang kurang pada anak hanya 39,1\% memiliki tinggi badan normal. Hasil Uji Korelasi Rank Spearman, didapatkan P value = $0,016(\mathrm{p}<0,05)$, terdapat hubungan antara asupan sumber zinc dengan kejadian stunting pada anak usia 3-5 tahun di Puskesmas Kopelma Darussalam dengan nilai r = 0,352 yang berarti kekuatan hubungan sedang.

\section{PEMBAHASAN}

Hasil penelitian terhadap 46 anak usia 3-5 tahun menunjukkan bahwa anak dengan tinggi badan terhadap umur (TB/U) yang stunting (pendek atau sangat pendek) yaitu 19 anak (41,3\%). Penelitian ini sejalan dengan penelitian Rahman dan Karim tahun 2014 di Bangladesh pada 726 anak didapatkan stunting pada anak laki-laki 43,1\% dan perempuan $\quad 50,3 \% .^{(12)}$ Penelitian Rahmad dan Miko tahun 2016 di Banda Aceh pada 50 anak usia 1-5 tahun didapatkan anak stunting 38,8\%. ${ }^{(13)}$ UNICEF melaporkan sepertiga anak-anak usia kurang dari lima tahun di negara berkembang memiliki tubuh pendek. Balita stunting di dunia 28,5\% dan negara berkembang 31,2\%. Stuntng menggambarkan status gizi kurang yang bersifat kronis akibat kebutuhan gizi tidak terpenuhi optimal. ${ }^{(2)}$ Hasil penelitian diperoleh 23 orang ibu (50\%) memiliki tinggi badan pendek $(<155 \mathrm{~cm})$. Hasil penelitian ini sejalan dengan penelitian Hanum dkk tahun 2014 terhadap $47 \mathrm{ibu}$ di Cianjur didapatkan 35 ibu (74,5\%) dengan tinggi badan pendek. ${ }^{(14)}$ Penelitian Zottarelli dkk tahun 2007 menunjukkan bahwa tinggi badan ibu yang pendek $(<150 \mathrm{~cm})$ cenderung memiliki anak yang stunting. ${ }^{\left({ }^{8}\right)} \mathrm{Ibu}$ yang pendek memiliki risiko hampir 2 kali memiliki balita stunting dibandingkan dengan ibu dengan tinggi badan normal. ${ }^{(11)}$ Berbagai faktor dapat mempengaruhi terjadinya stunting salah satunya yaitu status gizi orang tua, terutama status gizi ibu yang berkaitan dengan risiko kegagalan pertumbuhan intrauterine. Pertumbuhan janin yang terganggu akan berdampak pada 
pertumbuhan dan perkembangan anak yang lebih rendah. ${ }^{(14)}$ Hasil penelitian diperoleh sosial ekonomi rendah lebih dominan yaitu 24 orang (52,2\%). Hasil ini sejalan dengan penelitian Dwi dan Wirjatmadi tahun 2012 terhadap 52 responden di Gresik didapatkan keluarga dengan sosial ekonomi rendah berjumlah 32 orang (53,85\%). ${ }^{(15)}$ Penelitian Aramico dkk tahun 2013 menunjukkan bahwa keluarga dengan sosial ekonomi rendah berpeluang memiliki anak 21 kali lebih besar menyebabkan stunting. Hal ini berkaitan dengan kemampuan keluarga menyediakan makanan dalam jumlah yang cukup kepada anak untuk memenuhi kebutuhan gizinya dan rendahnya akses terhadap pelayanan kesahatan. ${ }^{(9)}$

Hasil penelitian diperoleh 23 anak (50\%) memiliki asupan sumber zinc kurang. Hasil ini sejalan penelitian Sulistianingsih dan Yanti tahun 2015 terhadap 48 anak di Bandar Lampung didapatkan anak dengan asupan sumber zinc kurang sebanyak 19 anak $(39,6 \%) .{ }^{(16)}$ Penelitian Kusudaryati tahun 2014 bahwa penyebab stunting pada anak salah satunya disebabkan kurangnya asupan makanan yang mengandung zinc. ${ }^{(10)}$ Menurut UNICEF asupan makanan yang kurang terutama protein dan sumber energi yang kaya akan sumber zinc merupakan penyebab tingginya prevalensi stunting. ${ }^{(2)}$ Hasil penelitian menunjukkan ibu dengan tinggi badan normal cenderung memiliki anak dengan tinggi badan normal yaitu 82,6\%, sedangkan ibu dengan badan pendek hanya 34,8\% memiliki anak dengan tinggi badan normal. Hasil Uji Korelasi Rank Spearman, didapatkan $\mathrm{P}$ value $=0,000(\mathrm{p}<0,05)$, terdapat hubungan antara tinggi badan ibu dengan kejadian stunting pada anak usia 3-5 tahun di Puskesmas Kopelma Darussalam dengan nilai $r=0,529$ yang berarti kekuatan hubungan kuat.

Penelitian ini sejalan dengan penelitian Zilda dan Trini tahun 2013 nilai $\mathrm{P}$ value $=0,03$ $(\mathrm{p}<0,05)$ terdapat hubungan antara tinggi badan ibu dengan kejadian sunting pada balita. ${ }^{(11)}$ Penelitian Amin dan Julia tahun 2014 nilai P value $=0,01(\mathrm{p}<0,05)$, terdapat hubungan antara tinggi badan ibu dengan kejadian stunting pada balita. ${ }^{(17)}$ Anak yang lahir dari ibu dengan tinggi badan $\leq 150 \mathrm{~cm}$ mempunyai risiko 30,8\% lebih tinggi mengalami stunting, sedangkan anak dari ibu dengan tinggi badan $>150 \mathrm{~cm}$ mempunyai risiko lebih kecil mengalami stunting. Secara genetik orang tua dengan tinggi badan pendek akan menurunkan sifat pendek kepada anaknya. Tinggi badan orang tua memberikan efek terhadap pertumbuhan seorang anak. Jika salah satu orang tua memiliki tinggi badan yang kurang ideal, maka anak akan memiliki tinggi badan yang sama dengan orang tuanya. ${ }^{(8)}$ Orang tua yang pendek karena gen dalam kromosom yang membawa sifat pendek akan menurunkan sifat pendek tersebut kepada anaknya, karena genetik 
seseorang diwariskan dari orang tua melalui gen. Kebanyakan tinggi badan anak diturunkan dari ibu karena apabila ibu memiliki tinggi badan pendek dapat meningkatkan risiko kegagalan pertumbuhan intrauterine. Pertumbuhan janin yang terganggu akan berdampak pada pertumbuhan dan perkembangan anak yang lebih rendah. ${ }^{(14)}$ Hasil penelitian menunjukkan bahwa keluarga dengan sosial ekonomi sedang cenderung memiliki anak dengan tinggi badan normal 62,5\%, keluarga dengan sosial ekonomi tinggi memiliki anak dengan tinggi badan normal 50\%. Hasil Uji kolerasi Rank Spearman, didapatkan P value =0,930 ( $>00,05)$, tidak terdapat hubungan antara sosial ekonomi dengan kejadian stunting pada anak usia 3-5 tahun di Puskesmas Kopelma Darussalam.

Penelitian ini sejalan dengan penelitian Ayuningtias tahun 2016 nilai $\mathrm{P}$ value $=0,786$ $(\mathrm{p}>0,05)$, tidak terdapat hubungan antara sosial ekonomi dengan kejadian stunting pada balita. ${ }^{(18)}$ Hasil penelitian ini berbeda dengan penelitian Aramico dkk tahun 2013 nilai $\mathrm{P}$ value $=0,000$ $(\mathrm{p}<0,05)$, terdapat hubungan antara sosial ekonomi dengan kejadian stunting pada balita. ${ }^{(9)}$ Ayuningtias menambahkan bahwa TB/U merupakan penilaian status gizi masa lampau, sementara sosial ekonomi hanya menunjukkan rekaman waktu yang lebih singkat. ${ }^{(18)}$ Pendapatan keluarga akan mempengaruhi pemenuhan zat gizi keluarga. Makanan seperti daging sapi, daging ayam dan ikan laut yang kaya akan sumber zinc dan sumber protein sulit terpenuhi sehingga kejadian stunting lebih tinggi pada keluarga dengan sosial ekonomi kurang. ${ }^{(9)}$ Hasil penelitian menunjukkan asupan sumber zinc yang baik pada anak cenderung memiliki tinggi badan anak normal sebanyak 78,3\%, sedangkan asupan sumber zinc yang kurang pada anak hanya 39,1\% memiliki tinggi badan normal.

Hasil Uji Korelasi Rank Spearman, nilai P value $=0,016(\mathrm{p}<0,05)$, terdapat hubungan antara asupan sumber zinc dengan kejadian stunting pada anak usia 3-5 tahun di Puskesmas Kopelma Darussalam dengan nilai $r=0,352$ yang berarti kekuatan hubungan sedang. Penelitian ini sejalan dengan penelitian Bahmat tahun 2010 didapatkan $\mathrm{P}$ value $=0,000(\mathrm{p}<0,05)$, terdapat hubungan antara asupan sumber zinc dengan kejadian sunting pada balita. ${ }^{(7)}$ Penelitian Laila tahun 2017 didapatkan $\mathrm{P}$ value $=0,001(\mathrm{p}<0,05)$, terdapat hubungan antara asupan sumber zinc dengan kejadian sunting pada balita. ${ }^{(19)}$ Zinc berperan penting dalam struktur dan fungsi biomembran, zinc menjadi komponen penting beberapa enzim yang mengatur sel pertumbuhan, sintesa protein dan DNA, metabolisme energi, pengaturan transkripsi gen, kadar hormon dan metabolisme faktor pertumbuhan. ${ }^{(7)}$ Zinc sangat berperan dalam proses pertumbuhan dan 
pembelahan sel khususnya sintesa dan degradasi karbohidrat, protein, lemak dan asam nukleat. Asupan sumber zinc akan meningkatkan konsentrasi plasma Insulin- like Growth Factor (IGF-I) yang dapat memicu kecepatan pertumbuhan karena IGF-I berperan sebagai growth promoting faktor dan proses pertumbuhan. ${ }^{(10)}$

\section{KESIMPULAN}

Tinggi badan ibu dan asupan sumber zinc berhubungan dengan kejadian stunting dan tidak terdapat hubungan sosial ekonomi dengan stunting pada anak usia 3-5 tahun di Puskesmas Kopelma Darussalam Banda Aceh. Prevalensi stunting anak usia 3-5 tahun di 5 posyandu Puskesmas Kopelma Darussalam sebesar 41,3\%.

\section{SARAN}

Perlu penyuluhan dan edukasi tentang pentingnya asupan sumber makanan zinc kepada masyarakat, khususnya ibu untuk mencegah stunting pada anak terutama kelompok balita. Diharapkan peneliti selanjutnya dapat melakukan penelitian terkait hubungan kadar zinc dalam darah dengan kejadian stunting pada balita.

\section{REFERENSI}

1. Amosu AM, Degun AM, Atulomah NOS, Olanrewju MF. A Study of the Nutritional Status of Under-5 Children of Low-Income Earners in a South-Western Nigerian Community. Curr Res J Biol Sci. 2011;3(6):578-85.

2. UNICEF. A Post-2015 World Fit for Children A review of the Open Working Group Report. Vol. 4. 2015. p. 7.

3. World Health Organization. Global and regional trends by WHO Regions, 1990-2016 Stunting [Internet]. 2016. Available from: http://apps.who.int/gho/data/view.m ain.NUTWHOSTUNTINGv?lang=e n [Diakses pada tanggal 30 Mei 2017]

4. World Health Organization. Nutrition landscape information system (NLIS)country prfile indicators: intrepretation guide. 2010;20(1):1-4. Available from: http://apps.who.int/iris/bitstream/10 665/44397/1/9789241599955_eng.p df [Diakses pada tanggal 31 Mei 2017]

5. Badan Penelitian dan Pengembangan Kesehatan. Riset Kesehatan Dasar (RISKESDAS) 2013. Lap Nas 2013. 2013;1-384.

6. Kementerian Kesehatan. Profil Kesehatan Indonesia 2014 [Internet]. Vol. 51, Kementerian Kesehatan Republik Indonesia. 2015. 40 p. Available from: http:/www.depkes.go.id/resources/ download/pusdatin/profil- kesehatanindonesia/profil- kesehatan-indonesia-2014.pdf [Diakses pada tanggal 3 Juni 2017]

7. Bahmat DO, Bahar H, Jus'at I. Hubungan Asupan Seng, Vitamin A, Zat Besi Dan 
Kejadian Pada Balita (24-59 Bulan) Dan Kejadian Stunting Di Kepulauan Nusa Tenggara (Riskesdas 2010). 2010;(Riskesdas):1-13.

8. Zottarelli LK, Sunil TS, Rajaram S. Influence of parental and socioeconomic factors in stunting in children under 5 years in Egypt. East Mediterr Heal J. 2007;13(6):1330-42.

9. Aramico B. Hubungan sosial ekonomi, pola asuh, pola makan dengan stunting pada siswa sekolah dasar di Kecamatan Lut Tawar, Kabupaten Aceh Tengah. 2013;1(3):121-30

10. Kusudaryati DPD. Kekurangan Asupan Besi dan Seng Sebagai Faktor Penyebab Stunting Pada Anak. J Profesi. 2014;10(26):58-9

11. Zilda O, Trini S. Faktor Risiko Stunting pada Balita (24-59 Bulan) di Sumatera. 2013;8(November):175-80.

12. Rahman MA, Karim R. Prevalence of Stunting and Thinnes Among Adolescents in Rural Area of Bangladesh. J Asian Sci Res [Internet]. 2014;4(1):39-46. Available from: http:/www.pakinsight.com/pdf- files/oth/2/jasr-4(1)39-46.pdf [Diakses pada tanggal 17 November 2017]

13. Miko A, Rahmad AH. Kajian Stunting pada Anak Balita Berdasarkan Pola Asuh dan Pendapatan Keluarga di Kota Banda Aceh. Jurnal Kesmasindo. 2016;8(2):58-77.

14. Hanum F, Khomsan A. Hubungan Asupan Gizi dan Tinggi Badan Ibu dengan Status Gizi Anak Balita. Jurnal Gizi dan Pangan. 2014;9(1):1-6.

15. Dwi WB, Wirjatmadi B. Beberapa Faktor yang Berhubungan dengan Status Gizi Balita Stunting. 2012;99-104

16. Sulistianingsih A, Ari MYD. Kurangnya Asupan Makan Sebagai Penyebab Kejadian Balita Pendek ( Stunting ). Dunia Kesehat. 2013;5:71-5.

17. Amin NA, Julia M. Faktor Sosiodemografi dan Tinggi Badan Orang Tua serta Hubungannya dengan Kejadian Stunting pada Balita Usia 6-23 Bulan. J Gizi dan Diet Indonesia. 2014;2 nomor 3(September 2014):174-80.

18. Ayuningtias. Hubungan Karakteristik Keluarga Dengan Kejadian Stunting Pada Anak Baru Sekolah. 2016

19. Laila SE. Hubungan Antara Asupan Zink dengan Kejadian Stunting pada Remaja di Sukoharjo Jawa Tengah. 2017 